\title{
Trotsky's thought and its influence
}

\author{
Wang Yi yao \\ Sichuan ideological and Political Education Research Center for college students of China West \\ Normal University; School of Marxism of Chinese Academy of Social Sciences \\ Sichuan ideological and Political Education Research Center forcollege students of \\ ChinaWestNormalUniversity, No 1 Shi Da Road, Nanchong City, Sichuan Province, \\ P.R.China637009 \\ wangyiyaoian@126.com
}

Key Words: Trotsky; Thought; Influence; Soviet Union; The international communist movement Abstract: Trotsky has been one of the controversial historical figures. The purpose of this study is to examine Trotsky's thought and its influence. A quantitative research method is adapted based on a survey with 20 questions among 25 doctoral candidates. Results may indicate that the research paper in the field of study is worthwhile for the history of international communist movement and the Soviet Union. Furthermore, the roles of Trotsky's thought and its influence have an important impact. Finally, it is urgent to examine the complexity and uniqueness of the thought of Trotsky, a great thinker with little popularity.

\section{Method}

The main purpose of the research on Trotsky's thought and its influence is to give further research to the history of the Soviet Union, the international communist movement history and foreign Marxism, and explore the socialist essence and law of the development of human society by this questionnaire. The relevant data of Trotsky's thought and its influence will be collected by surveying Marxism theory about professional scholar, master degree candidate and candidate for doctorate. Twenty five questionnaires are sent to Marxism freshmen enrolled in the school of Marxism, and Twenty five evaluable questionnaires are collected. The participants come from the students of the Chinese Academy of Social Science (CASS).These types of problem in this questionnaire includes open and closed questions, single and multiple response, ranked responses, rated responses and so on. In total, the researcher spent a month or so in the questionnaire. The data will be analyzed by Likert Scaling and SPSS (Statistical Product and Service Solutions).

\section{The origin and development of Trotsky thought}

Today, no one seems to question the important role Trotsky played in the Russian history. Eighty-four percent people mainly know the related stories and information of Trotsky by Documents. (table1)In 1896, Trotsky was one of founders of the organization of the South Russian Union of workers. Trotsky participated in the leadership of the Russian Revolution of 1905. During the Russian revolution in 1905, Trotsky went back to Russia from Finland and was elected as St.Petersburg Soviet President in December. After such a short but intense high tide of revolution Trotsky was soon arrested. (Trotsky, 1)On September 23, 1917, Trotsky was elected as St.Petersburg Soviet President again, and in October, 1917 he played a leading role in armed 
uprising of the organization of Petrograd revolutionary committee.(F I Nevski,327) As chairman of the St.Petersburg Soviet Trotsky ordered masses of laborers to rise in arms. On November $6^{\text {th }} 1917$, in accordance with the commands of Lenin, the Bolshevik Party Central Committee had decided to launch an armed uprising. Trotsky set his headquarters in palace of Smolny and personally commanded the October Revolution. In fact, only fifty-five percent people know that in the 1905

Revolution and the 1917 Revolution, Trotsky was elected as the Chairman of the Petrograd Soviet workers. Thirty-six percent people have the misconception that in the 1905 Revolution and the 1917 Revolution, Lenin was elected as the Chairman of the Petrograd Soviet workers.(table2) Trotsky had given important contribution to the victory of socialist revolution.(Qiao, 16)He set up the Red Army and won the war in the country. He used to be Lenin's close comrade in arms and he was even highly parallel to Marx and Lenin. However, in the Stalin era Trotsky was constantly attacked as a counterrevolutionary role. He was sentenced to spend the rest of his life in exile overseas. From then on, he became an author and he established the fourth international in September, 1938. It is a pity that Trotsky was eventually assassinated by Soviet agents on August 20, 1940 and he died inMexico.As Mr. ZhengYifansaid:"In the history of the international communist movement so far there have not been the last words of at least two people. As the Contradictory body, they are absolutely irreconcilable enemies. And they have not gained generally accepted version after their death. They are Trotsky and Stalin."(Zheng, 2008)

Table1

\begin{tabular}{|l|c|c|c|}
\hline \multicolumn{1}{|c|}{ options } & subtotal & \multicolumn{2}{c|}{ The proportion } \\
\hline Media reports & 4 & & $16 \%$ \\
\hline Elders tells the story & 0 & & $0 \%$ \\
\hline Documented & 21 & & $12 \%$ \\
\hline The revolutionary story & 3 & & $0 \%$ \\
\hline chat & 0 & & $28 \%$ \\
\hline Network query & 7 & & $0 \%$ \\
\hline
\end{tabular}

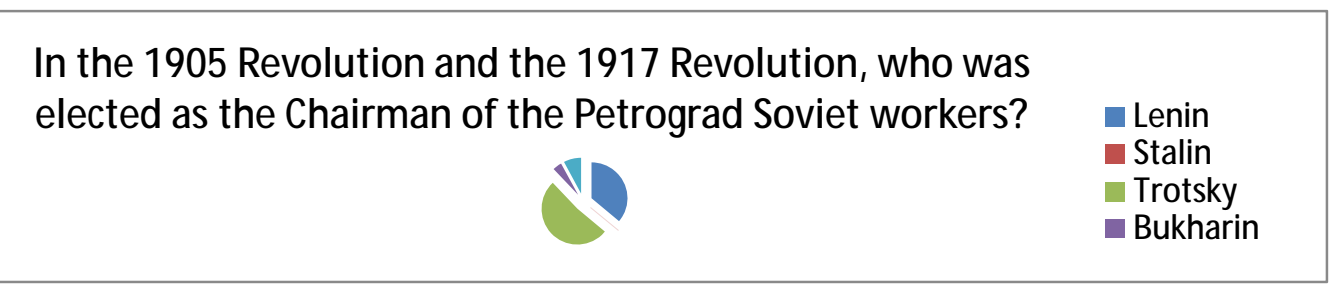

Table2

\section{Historical support}

Trotsky was the so-called encyclopedic character (Trotsky, 2011), but as a thinker, Trotsky was rarely known by people. Trotsky, a prolific author, lived by his pen from the cradle to the grave. As is known to everyone, there are a total of 60 volumes of the Chinese version of the complete Works of Lenin. However, the complete Works of Trotsky published abroad is as many as 150 volumes. Speaking of such things, it is a remarkable piece. Trotsky had profound theoretical knowledge and open field of vision and a large stock of information involved in many areas of political, economic, military, diplomatic and cultural sphere of learning. He had many achievements. For example, the 
'fellow traveler' concept the Russian Literature came from his pen; the economy academic language of 'scissors' is his creation.

\section{The revolutionary prophet}

Of course, his main writings consist of his revolutionary theory and so that he was respected as 'The Prophet' by his follower Isaac Deutscher who is from Poland. The prophet trilogy, it consists of three volumes the first volume of the armed prophet: Trotsky, 1879-1921was published in 1954 in London; the second volume the disarmed prophet: Trotsky, 1921-1929 was published in 1959 in London; the third volume the exiled prophet: Trotsky, 1929-1940 was published in 1963 in London. The prophet trilogy is one of the most comprehensive and detailed Trotsky's biographies, and so far The prophet trilogy have been one of the most influential classic works of Trotsky.

\section{Permanent revolution theory}

Permanent revolution theory is the most important theory of Trotsky. Forty percent people are aware of the fact that Trotsky advances the theory of permanent revolution. Thirty-six percent people know it, but they are unclear about the theory of permanent revolution. (Table3)Maybe owing to decades of man-made deliberate oppression and political blockade and other reasons, most people in China do not understand their theories and ideas. Although his opponents can point out many deficiencies, much of his theories of permanent revolution, world revolution theory, socialist transition theory, Cultural Revolution theory and other revolutionary theory and doctrine, objectively speaking, are full of correct and profound insight and unique innovation of the Marxist insights. Trotsky advocate that it is advisable to look at the class and ideological struggle with the view of the process of internationalism "The process of class struggle and the struggle of ideology completely and thoroughly move away problems from reminiscent realms of quondam disagreement or controversy of the Russian Marxists, and become a problem of nature, internal relations and methods of the whole international revolution." (Trotsky,234)

Table3

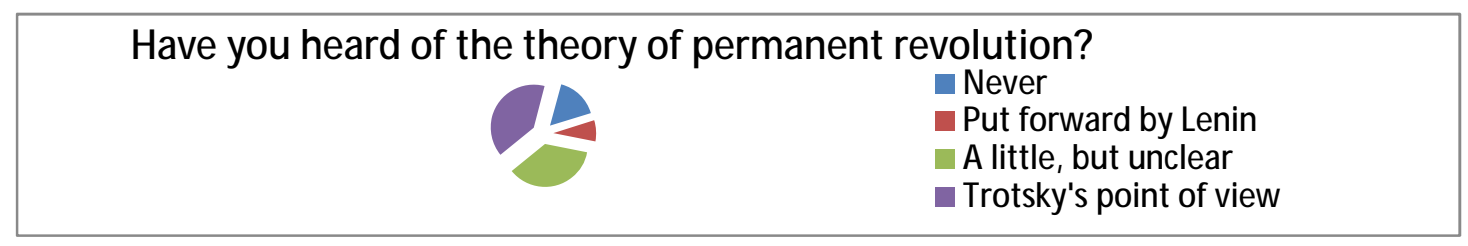

The fundamental cause of the October revolution crisis is the delay of the world revolution caused by a series of tragic failure of the proletariat. (Duimazongxing, 121)Japanese scholar Duimazongxing believes that there is a crisisin the October revolution per se. A series of failures of the proletariat exacerbated the crisis. Therefore, Duimazongxing actually shows his agreement with permanent revolution theory of Trotsky.

\section{Discussions and Recommendations}

\section{The controversial historical figure}

Trotsky is one of the leading lights of both Soviet History and the history of international communist movement. Researchers must give a sufficient study to the question. There's no getting round it.And Trotsky has been one of the controversial historical figures in the history of socialism 
in twentieth Century. Trotsky, a revolutionary, has attracted much attention.

Up to the present, the debate about Stalin has been still in progress and will undoubtedly continue in the future. And on Trotsky, his fate seems to always be tragic. Before the disintegration of Soviet Union, his thoughts and ideas are offbeat in the revolutionary ranks and he had been treated as the object of attack by the trend of international anti-communism. Because of drastic changes in Eastern Europe and Disintegration of the Soviet Union and the low tide of socialism, the Communist Party had rectified his reputation for him. With the declassification of related documents the truth gradually surfaces. There have been increasing understanding and tolerance of the diversity of Socialist mode and the diversification of socialist movement. Therefore, although objective comments are based on precise and meticulous research foundation, it is time to take an objective comment on his merits and demerits.

Trotsky's thought of centralization of state power of the Soviet Union bring about a totalitarian problem exploration of the Soviet Union. In fact, this also refers to the essence and the future of socialism and the Soviet Union. By the moment of those last debates and the writing of The USSR in War, Trotsky had opened the in principle possibility that the USSR might be a new form of totalitarian regime. (Beilharz, 128 )

\section{A Marxist}

Considering this research aimed to catch Trotsky's thought and its influence. In general, there is no doubt that he is a Marxist. Therefore, Trotsky deserves proper respect and historical position in the history of the development of socialist thought and movement. In a nutshell, Trotsky has been able to obtain world-wide influence. He participated in the leadership of the October Revolution and was involved in the prolonged political events with Stalin and other major expansion. More importantly, because his theories are full of the excellent complexity and the exclusive uniqueness. In 1898, he and the South Russian Workers' Union were imprisoned. When hewas inprison, he married a fellow Marxist -Aleksandra Sokolovskaya.'Two years later, he was exiled to Siberia for 4 years (1898-1902) for being a Marxist.'(Parkinson and Greaves, 258)

\section{History echo of Trotsky's thought}

One of the most important ideas of Trotsky is that socialist revolution begins from one country, but must be completed on the world stage. The socialist revolution must adhere to the principle of internationalism. "It is conceivable that socialist construction only depend on the basis of development of class struggle within the national and international scope."(Trotsky, 236)It appears that Trotsky's points of view are that it is impossible in a single country to build socialism. With its opposite, Stalin's standpoint of Soviet Union is that a country can build a socialist.

Trotsky's theory of "one country cannot build socialism" is a kind of rigorous theoretical thinking concerning the future of human society, especially the global political and economic development direction and the mutual relation and interaction of Soviet Russia socialism development and the world politics and economy. "Today we have to think like this, the theory of building the socialist in one country is not only a matter of Stalin's creation, but it exactly and correctly expressed the bureaucratic mood."(Trotsky\&Cai, 214)Stalin lays claim to that Trotsky is in the position of anti-Soviet, anti-socialist and Trotsky is fundamentally against socialist construction of the Soviet Union. Actually, anyone with a little common sense may find out that Stalin'sway of looking at a thing is very flimsy. If Trotsky is against Soviet socialist construction, why does he participate in the leadership and the October Revolution to establish the proletariat regime? The truth is self-evident. 


\section{References}

[1]David McLellan, Marxism after Marx, Renmin University of China press, 2004.

[2]Duimazongxing (Japanese), (1984), "Trotskyism, Heilongjiang People's Publishing House.

[3]Jean-Paul Brodeur(2005)Trotsky in Blue: Permanent Policing Reform. TheAustralianandnewZealandJournalofCriminologyvolume 38 NUMBER 22005 PP. 254-267.

[4]Nicholas Parkinson and Ian Greaves(2012). Famous trauma victims -Leon Trotsky.trauma 14(3) $257-262$.

[5]F I Nevski(1986). Lev Davidovich Tolotskiy:1879-1940, Research Data on the History of International Communist Movement,3,320-328.

[6]Peter Beilharz(2003).Thedecline of western Marxism: Trotsky ,Gram-sci, Althusser.Review Essay Thesis Eleven, Number 75, November 2003: 126-134.

[7]Qiao Zhizong1997."Reappraisal on Trotsky". Teachingon Liberal Arts,2,14-20. Jining District: Jining Normal University.

[8]Ronald H. Chilcote(2009). Trotsky and Development Theory in Latin America.Critical Sociology 35(6) 719-741.

[9]Teaching and research section of Marxism-leninism, Renmin University of China(1956). theselected works on treason case of Trotsky group, Boharlin group and Beria group,Renmin University of China press.

[10]Trotsky\&CaiJinru'stranslations(1963). The betrayed revolution - the Soviet Union's current situation and its future. Shanghai: triple Bookstore information room.

[11]Trotsky,ZhengYifan'scomplements(2010),The selected works of Trotsky,people's publishing house.

[12]Trotsky,ShiYongqin'stranslations(2011) 《 Trotsky's discourse on Chinese revolution (1925-1927)》,Shaanxi People's Publishing House,Page18.

[13]Trotsky\&ShiWen\&ShiYongqin's translations $\quad$ (1996) Trotsky's Autobiography.ZhengYifan(2008). Trotsky reader - Introduction,Central Compilation \& Translation Press 2008,Page1. 